\title{
COLONEL (DR) JAN PLOEGER (1913-1994)
}

\author{
Major I.J. van der Waag \\ Documentation Service, SANDF
}

Jan Ploeger was born on 18 February 1913, in the small town of Noodbroek in the Dutch province of Groningen. He qualified as a primary school teacher and taught for three years. During this time he served with the Regiment Geniste (Netherlands). Worsening economic conditions in western Europe, however, enticed him to emigrate to South Africa in 1936.

Jan Ploeger immediately began to qualify himself in his new fatherland. He registered as a student at the University of Pretoria and was awarded a B.A. in 1938. This was followed by a M.A. in 1940 and a M.Ed. in 1943. He attained a D.Phil. (History) in 1945, under Professor I.D.Bosman. His thesis, "Onderwys en Onderwysbeleid in die Suid-Afrikaanse Republiek onder S.J. du Toit en Dr N. Mansvelt (1881-1900)", was published in the Archives Yearbook for South African History in 1952.

His colourful career of some 43 years as a teacher, temporary lecturer (Department of History, University of Pretoria), journalist, archivist and historian testifies to his love for history - a love which germinated on land in Groningen which had been reclaimed from the sea as early as 700 years before Christ. ${ }^{1}$

His love for history is also manifested in his prolific writing. In addition to countless articles in newspapers, periodicals and academic journals, Colonel Ploeger wrote a number of monographs. His largest contribution, however, is "Die lotgevalle van die burgerlike bevolking gedurende die Anglo-Boereoorlog, 1899-1902", which was commissioned by the State.

Jan Ploeger also left an indelible mark on South African military historiography. His military career commenced as early as 1939 , when he attested with the Regiment De la Rey for service during the Second World War. He later served with the Pretoria Regiment as a Second Lieutenant. After the war, he became a journalist and later a teacher. In 1964, he gave up his teaching post at Hillview High School and attested to the Permanent Force on 4 July of that year. He was appointed with the rank of commandant (now lieutenant colonel) and was posted to the Military Historical and Archival Service (the predecessor of Directorate Documentation Service).

During the late sixties, the Military Historical and Archival Service (MHAS) made its debut in the field of military history with Jan Ploeger in the vanguard. The MHAS publication programme included a military history journal called Militaria, and what was to be a yearbook series (they have since become known as the Black Publications series). In 1968, the first of these "yearbooks" was published. This contained Commandant Ploeger's study of the military forts in the Pretoria area and coincided with the restoration of forts Klapperkop and Schanskop. Commandant Ploeger served as the first editor from 1969 to 1973 . Over the years, Jan Ploeger contributed no less than 46 articles to Militaria, the last appearing in the March 1993 issue. Some 25 years and 100 issues later, Militaria still continues as the military history journal of South Africa's defence force.

Jan Ploeger was promoted to the rank of colonel with effect from 15 December 1972, but retired from his post as Senior Staff Officer Archives and Research on 28 February 1973.

He was subsequently appointed as a State Historian in a part-time capacity, commissioned to work on the Anglo-Boer War project. By 1980, he had produced a number of chapters on the civilian aspects of the Anglo-Boer war and compiled histories of all the English concentration camps. In these chapters, which reveal numerous hitherto unknown aspects of the war, he concentrated on the lifestyles, experiences, morale and the problematics of people in captivity. ${ }^{2}$ He finally retired in February 1987, by which time he had completed some 100 chapters. Some of these unpublished manuscripts have appeared as articles in, inter alia, the Quarterly Bulletin of the South African Library, the South African Jour-

N. Beek: "Kort huldeblyk en lewensskets van dr Jan Ploeger", Archives News XXXVI (9) Mar 1994, p. 29.

J. Ploeger : 'Suid-Afrikaanse staats- en staatsondersteunde militêre geskiedskrywing, 1924-1987', Militaria 19(4) 1989, p. 34 . 
nal for Cultural and Art History and Africana Notes and News.

Colonel Ploeger was fluent in Afrikaans, English, Dutch and Flemish, and could read Ger- man and French. He was member of numerous academic societies and associations, and recipient of several awards. In 1992, he received a medal for the promotion of history from the South African Academy for Science and Arts. His presence will be sorely missed. 